\title{
ÉTICA NO ENSINO DE CIÊNCIAS: O POSICIONAMENTO DE PROFESSORES DE CIÊNCIAS SOBRE ETICIDADE DURANTE A ABORDAGEM DO TEMA TRANSGÊNICOS E SUAS IMPLICAC̣ÕES SOCIOAMBIENTAIS
}

\begin{abstract}
RESUMO: Apresentamos os resultados de uma investigação com o que teve como objetivo de analisar os posicionamentos de seis professores de Ciências, no município de Tijucas, Santa Catarina, sobre ética no ensino de ciências durante a apresentação em sala de aula sobre o tema transgênicos. Para a coleta de dados, utilizamos entrevistas semiestruturadas. Para as análises, definimos três unidades: a natureza da eticidade, o discurso ideológico e o desenvolvimento moral e as atitudes dos professores de Ciências em situações de tensão. De maneira geral, constatamos que os professores apresentam aspectos importantes que caracterizam o tema transgênicos na prática docente, como o questionamento, valorizando, por exemplo, os registros e as informações oferecidas pela mídia em geral. Entretanto, alguns ainda parecem ter uma compreensão parcial de ética no ensino de Ciências, não explicitando aspectos importantes como seu posicionamento crítico e reflexivo sobre o uso dos transgênicos. Percebemos que eles apresentam noções sobre a de relacionadas a como "utilizar a ética", no entanto, ainda encontram dificuldades em efetivar, nas salas de aula, um processo de formação ética.
\end{abstract}

Palavras-chave: Ética. Ensino de Ciências. Transgênicos.

\section{ETHICS IN SCIENCE TEACHING: THE POSITIONING OF TEACHERS ON ETHICS DURING THE APPROACH TO THE THEME OF TRANSGENICS AND ITS SOCIOENVIRONMENTAL IMPLICATIONS}

ABSTRACT: We present the results of an investigation with the objective of analyzing the positions of six Science teachers in Tijucas, Santa Catarina on ethics in science teaching during the classroom presentation on the theme of transgenics. For data collection, we used semi-structured interviews. For the analyses, we defined three units: the nature of ethics, the ideological discourse and the moral development, as well as the attitudes of Science teachers in situations of tension. In general, we see that the teachers presented important aspects that characterize the theme of transgenics in their teaching practice, such as the questioning that values, for example, the records and the information offered by the media in general. However, some still seem to have a partial understanding of ethics in science teaching, not explaining important aspects, such as their critical and reflective positioning about the use of transgenics. We realized that such teachers have notions about the "use of ethics", but they still face difficulties in carrying out a process of ethical training.

Keywords: Ethics. Science education. Transgenics.
Wanderley Pivatto Brum*

Elcio Schuhmacher**

\footnotetext{
* Mestre em Ensino de Ciências Naturais e Matemática. Professor da Faculdade Avantis de Ensino (Balneário Camboríu). E-mail: ufsc2013@yahoo.com.br

* Doutor em Química pela Universidade Federal de Santa Catarina(UFSC). Professor do quadro - concursado da Fundação Universidade Regional de Blumenau. E-mail: elcio@furb.br
} 


\title{
INTRODUÇ̃̃̃O
}

Diante de novas tendências que emergem em diversas frentes do conhecimento humano, assistimos, no mundo, em geral, a uma inequívoca crise na esfera da moral e na ética (CARVALHO, 2009), (BIZZO, 2008), (VALE, 2009). A produção de conhecimento acerca de temas como neoliberalismo, globalização, clonagem, biologia molecular e biotecnologia conclama, cada vez mais, a participação da sociedade nos debates e na construção de soluções para os problemas atuais advindos desses temas. Transformações profundas e rápidas do mundo contemporâneo pedem que ninguém fique desatento ao curso dos fatos e acontecimentos, evidenciando-se a necessidade de um amplo debate em torno de questões éticas que transpassam todos os propósitos da humanidade (LA TAILLE, 1998).

As escolas não podem ficar longe desse debate em função de seu importante papel institucional na formação e na instrumentalização dos princípios éticos que orientam os rumos de uma sociedade. Apesar de gerarem posições polêmicas, em decorrência da inserção de propostas educativas não discutidas amplamente pelas bases interessadas, advindas da Lei 9.394/96 (Lei de Diretrizes e Bases da Educação Nacional) e dos Parâmetros Curriculares Nacionais (PCN), os princípios éticos envolvem uma perspectiva educacional positiva, fomentada por sua inclusão na formação docente. Sobre essa extensa literatura apresentada nos PCN, a ética:

\begin{abstract}
é um conhecimento que colabora para a compreensão do mundo e suas transformações, para reconhecer o homem como parte do universo e como indivíduo crítico. A apropriação de seus conceitos e procedimentos pode contribuir para o questionamento do que se vê e ouve, para a ampliação das explicações acerca dos fenômenos da natureza, para a compreensão e valoração dos modos de intervir na natureza e de utilizar seus recursos, para a compreensão dos recursos tecnológicos que realizam essas mediações, para a reflexão sobre questões éticas implícitas nas relações entre Ciência, Sociedade e Tecnologia (BRASIL,1998, p.21).
\end{abstract}

Aparece, ainda, nos documentos, a proposta de instituir o aprimoramento do estudante como pessoa humana, incluindo a formação ética e o desenvolvimento da autonomia intelectual e do pensamento crítico. Para isso, Oliveira (2006) enfatiza que faz-se necessário uma ação docente que estimule os estudantes a perguntar, refletir, agir eticamente, buscar por respostas e tomar decisões, de maneira que atuem ativamente na construção do conhecimento. Entretanto, o que acontece é que, na maioria das vezes, os conteúdos escolares não recebem tratamento adequado para esse fim. Em geral, o que a escola faz é se propor a atender, na melhor das hipóteses, ao desenvolvimento do raciocínio lógico do estudante e, com isso, deixa-se de lado a formação moral da pessoa do estudante (BICUDO, 2007).

Os Parâmetros Curriculares Nacionais de Ciências Naturais (BRASIL, 1998) alertam sobre o fato de a maioria da população conviver com produtos científicos e tecnológicos, mas que, devido à falta de informação, acabam não refletindo sobre questões que englobam a sua criação/produção, exercendo opções subordinadas ao mercado, o que acaba impedindo o exercício ético, crítico e 
consciente da cidadania. Parece necessário, a partir do exposto, que reflexões sejam feitas sobre o atual desempenho da escola na formação e no desenvolvimento moral dos estudantes, dadas as dificuldades que podem passar pelo caminho de tais propósitos e atentos ao fato de que não são poucos, e muito menos simples, os problemas da educação brasileira.

Entre as diversas dificuldades, Vasconcelos (2008) alerta para a grande diversidade encontrada em sala de aula, indicando a existência de "vários mundos quantos forem as pessoas lá presentes" (VALE, 2009, p. 132), com variado quadro de valores, crenças, expectativas e ansiedades, em que cada um carrega sua história, sua classe social, seu tipo físico, sua participação em grupos exclusivos que, às vezes, apresentam uma linguagem própria. Nesse caso, se a comunicação do professor for baseada na autoridade, no discurso unilateral e na negligência para proporcionar debates respeitosos, surgirão sérios problemas e inconvenientes, tanto do ponto de vista moral e ético, como intelectual.

Assim, o objetivo deste artigo é apresentar os resultados da investigação desenvolvida junto a professores de Ciências da rede pública de Tijucas, Santa Catarina, com relação à contemplação de questões éticas no ensino de Ciências, com enfoque na abordagem sobre transgênicos. Consideramos como justificativa a demanda escolar sobre temas contemporâneos da Biologia e a incipiente produção acadêmica acerca do ensino de Genética. O trabalho, em sua sequência, apresenta aspectos teóricos sobre a natureza da eticidade, os discursos ideológicos e o desenvolvimento moral, atitudes de professores em situações de tensão, a metodologia da investigação, seus resultados e análises, bem como algumas considerações de teor geral.

A ideia desta pesquisa sobre ética no ensino de Ciências surgiu após leituras dos trabalhos de Razera (2000). e Razera e Nardi (2006) que examinaram o posicionamento docente no ensino de temas controversos, como o debate entre criacionismo e evolucionismo.

\section{A NATUREZA DA ETICIDADE}

O homem vive em sociedade, convive com outros homens e, portanto, cabe-lhe pensar em responder à seguinte pergunta: "Como devo agir perante os outros?". Trata-se de uma pergunta fácil de ser formulada, mas difícil de ser respondida. Ora, essa é a questão central da ética. Para entender as concepções de ética dos indivíduos, Trasferetti (2006) comenta que se faz necessário conhecer as concepções apresentadas na literatura até o momento. Sabe-se que a ética está diretamente ligada aos princípios e valores que determinam a conduta humana em relação ao meio. Segundo Fourez (1995), a ética pode ser definida como o estudo dos juízos de apreciação referentes ao tratamento humano, do ponto de vista não somente do bem e do mal, mas do correto e incorreto, verdadeiro e falso. Ou ainda, segundo o mesmo autor, a ética é um conjunto de normas e princípios que norteiam a boa conduta do ser humano. Vázquez (2002) defende que é a ciência 
do comportamento moral dos homens no meio social. Assim, toma como ponto de partida a multiplicidade de morais através do tempo, com valores, princípios e normas próprios. Deve, portanto, investigar e explicar o princípio que permita compreendê-las no seu movimento e desenvolvimento.

Como se pode perceber, há um certo consenso entre Fourez (1995) e Vázquez (2002) ao afirmarem que a ética se refere ao comportamento humano, orientado por regras de boa conduta na convivência em sociedade. O que não se pode é estabelecer como são esses comportamentos ou o que é certo ou errado, pois isso dependerá do cenário no qual o indivíduo estará inserido. As atitudes, relembram Zajdsznajder (1999) e Vázquez (2002), serão determinadas pelo tempo histórico, pela localização, pela sociedade na qual o sujeito vive; seu comportamento será definido pelo cenário por ele ocupado.

A ética pode ser entendida, segundo Vázquez (2002), como um estudo ou uma reflexão sobre ações, costumes ou comportamentos. É de extrema importância destacar que a ética está diretamente ligada aos hábitos e costumes, e esses mudam de acordo com o tempo e a localização. Sendo assim, o que é considerado ético hoje, pode não o ser amanhã e o que é considerado certo em determinado país ou localidade, pode não o ser em outro. Valls (2000) traz, assim, uma definição mais abrangente de ética, entendo-a como os hábitos e comportamentos aceitos em determinado espaço de tempo e em determinada localidade de acordo com os costumes vigentes, enquanto considerados morais pela maioria da sociedade, deixando clara a condição situacional da ética.

Os grandes pensadores da ética buscaram uma universalização dos princípios éticos. No entanto, a grande diversidade de costumes e culturas torna difícil essa universalidade. Alguns pensadores destacaram-se, conforme mostra Valls (2000), e não podem deixar de ser citados no estudo da ética. Na Grécia antiga, entre os anos de 500 e 300 antes de Cristo (a.C), aproximadamente, pode-se encontrar inúmeras reflexões acerca da ética que são de extrema importância não somente para aquele tempo, mas para todo o fundamento do pensamento sobre a ética até os dias de hoje.

Dentre eles, Valls (2000) relembra o grego Sócrates, que viveu entre 470 e 399 a.C., e que se destaca por ter desafiado a cidade/estado questionando as leis, mesmo obedecendo-as, fazendo com que o conservadorismo grego o condenasse a beber veneno. Apesar de não ter deixado nada escrito, seus ensinamentos podem ser observados por intermédio dos seus discípulos, dentre eles Platão, em seus diálogos. Séculos depois, Sócrates foi chamado de fundador da moral, pela tentativa de compreensão da justiça através da sua convicção pessoal. Valls (2000) aborda moral como sinônimo de ética, com pequeno destaque para a interiorização das normas. Para muitos, Sócrates foi considerado o primeiro pensador da subjetividade, com a interiorização da reflexão.

Platão, que viveu entre 427 e 347 a.C., discípulo de Sócrates, acreditava que todos os homens estavam em busca da felicidade, no entanto, sempre se questionava onde estaria esse bem supremo. Platão parecia acreditar em uma vida após a morte, demonstrando, em seus diálogos, a espera da felicidade especialmente 
depois do óbito. Ele acreditava que esta vida devia servir de contemplação de ideias, dentre elas, a principal, a ideia do bem. Segundo Mattar (2004), Platão teve outra importância, fundando o que pode ser considerada a primeira universidade da história da humanidade, a Academia.

Outro autor que aborda a ética de forma abrangente é Singer (2002), que traz questões de natureza prática como a igualdade para as mulheres, o aborto, a eutanásia, a biologia molecular, e utiliza, indiferentemente, as palavras ética e moral. Afirma que, para alguns, a ética pode ser vista como uma série de proibições ligadas ao sexo e, para outros, pode ser confundida como algo bonito na teoria, mas que não funciona na prática. Segundo o autor, isso acontece porque as pessoas acreditam que a ética é um conjunto de normas simples e breves como não matar, não mentir, mas na vida real acontecem coisas inusitadas e complexas. Daí, surge a concepção consequencialista, em que uma ação será ética ou não, dependendo das consequências que o ato acarretar, do discurso apresentado ou do nível de desenvolvimento moral fomentado no indivíduo.

\section{DISCURSOS IDEOLÓGICOS E OS ESTÁGIOS DE DESENVOLVIMENTO MORAL}

As pesquisas de Kohlberg (1992) incluem-se no grupo das teorias cognitivo-evolutivas, assim como as de Piaget (1996), tendo como base o pressuposto de que o desenvolvimento pressupõe transformações básicas da estruturas cognitivas, enquanto totalidades organizadas em um sistema de relações. Kohlberg (1992) considera três níveis hierárquicos de desenvolvimento moral, cada qual com dois estágios (Quadro 1).

Quadro 1: Níveis hierárquicos do desenvolvimento moral, a partir da teoria de Kohlberg.

\begin{tabular}{|c|c|c|}
\hline \multicolumn{3}{|c|}{ Níveis hierárquicos do desenvolvimento moral } \\
\hline Nível 1 & Nível 2 & Nível 3 \\
\hline $\begin{array}{c}\text { Pré convencional } \\
0 \text { indivíduo apoia-se em } \\
\text { interesses próprios }\end{array}$ & $\begin{array}{l}\text { Convencional } \\
0 \text { indivíduo se baseia em } \\
\text { regras sociais }\end{array}$ & $\begin{array}{c}\text { Pós convencional } \\
0 \text { indivíduo é guiado por } \\
\text { princípios universais pautados } \\
\text { pela reciprocidade e igualdade }\end{array}$ \\
\hline $\begin{array}{c}\text { Estágio } 1 \\
\text { (modalidade heterônoma) } \\
0 \text { indivíduo obedece às } \\
\text { normas por medo do } \\
\text { castigo que pode vir } \\
\text { a receber. }\end{array}$ & $\begin{array}{c}\text { Estágio } 3 \\
\text { (comportamento exemplar) } \\
0 \text { indivíduo cumpre com aquilo } \\
\text { que é devido e esperado. }\end{array}$ & $\begin{array}{c}\text { Estágio } 5 \\
\text { (contratual-legalista) } \\
\mathbf{0} \text { indivíduo considera o } \\
\text { contrato social e os direitos } \\
\text { individuais. }\end{array}$ \\
\hline $\begin{array}{c}\text { Estágio } 2 \\
\text { (individualismo) } \\
0 \text { indivíduo apresenta } \\
\text { um raciocínio moral } \\
\text { egocêntrico }\end{array}$ & $\begin{array}{c}\text { Estágio } 4 \\
\text { (manutenção da ordem social) } \\
0 \text { indivíduo apresenta um } \\
\text { comportamento que segue as } \\
\text { regras das instituições. }\end{array}$ & $\begin{array}{c}\text { Estágio } 6 \\
\text { (hermenêutica) } \\
0 \text { indivíduo segue os princípios } \\
\text { éticos universais de justiça. }\end{array}$ \\
\hline
\end{tabular}


No nível 1, as regras e normas da sociedade são completamente externas ao sujeito, isto é, o indivíduo adapta-se às regras que lhe são impostas pelas figuras de autoridade para evitar um castigo ou para obter recompensas. Dentro desse nível, Kohlberg (1992) apresenta dois estágios do desenvolvimento moral. No estágio 1, a criança tem um ponto de vista egocêntrico e, por isso, apresenta um "respeito" egocêntrico em relação à autoridade, isto é, adapta-se às regras para evitar um castigo ou para receber uma recompensa, "decidindo o que está certo ou errado com base nas suas consequências" (KOHLBERG, 1992, p. 43). Para Kohlberg (1992), a criança, em seu discurso, não se preocupa com os diferentes pontos de vista e não consegue interpretá-los em simultâneo. A criança não tem noção da regra, nem consegue avaliar as intenções, sendo que para ela a gravidade de uma situação está relacionada com as consequências que esta pode trazer.

No estágio 2, conforme Rest et al. (1999), o indivíduo tem uma mentalidade egoísta, agindo corretamente e satisfazendo suas necessidades apenas de modo ocasional. A criança, em seu discurso ideológico, se posiciona com obediência à autoridade não só para evitar castigos e receber recompensas, mas também para satisfazer alguma necessidade pessoal, ou seja, apenas deve obedecer às regras quando se trata do interesse imediato de alguém, agindo de forma a satisfazer os próprios interesses ou necessidades e deixar os outros fazerem o mesmo. A criança apenas faz coisas aos outros se eles lhe retribuírem o favor, lembra Kohlberg (1992), "reciprocidade", sendo que ela não tem uma verdadeira noção da regra, pois para ela a gravidade de uma má ação depende da intenção de quem a pratica.

No nível 2, Kohlberg (1992) afirma que os indivíduos já interiorizam e adotam, como sendo suas, as regras morais, e esforçam-se por obedecer às regras estabelecidas por outros para obter reconhecimento pelo seu comportamento. O indivíduo, em seu discurso ideológico, considera correto aquilo que está conforme e que respeita as regras, as expectativas e as convenções da sociedade. Dentro do nível 2, existem os estágios 3 e 4 . No estágio 3, as ações são avaliadas de acordo com as intenções de quem as pratica, sendo que o principal objetivo é ser considerado boa pessoa, ter boas intenções e estabelecer relações com os outros. Para Bataglia (2001), o indivíduo passa agora a ter um pensamento mais abstrato, começando a preocupar-se com aquilo que os outros pensam ou sentem. A família e os pequenos grupos começam a tornar-se mais importantes, sendo que aquilo que importa é corresponder às expetativas das pessoas mais próximas ou aquilo que as pessoas esperam dos indivíduos, o que pode provocar várias vulnerabilidades (CARMINO; MORAES; GALVÃO, 2006).

Kohlberg (1992) compreende que o estágio 4 está relacionado com a obediência e com o respeito pelas leis e autoridade e pelas expetativas que a sociedade deposita nas pessoas. A realização dos deveres faz-se não tanto para evitar a punição, mas com o objetivo de manter a ordem social, considerando que as leis existem para serem cumpridas e que a sociedade espera que cada um cumpra o seu dever. A justiça obriga que aquele que infringir a lei seja "castigado" e que aqueles que obedecem às regras sejam recompensados, sendo que 
um comportamento é considerado correto ou moral segundo a forma como se enquadra nas regras da sociedade.

No nível 3, o indivíduo considera, em seu discurso ideológico, diversos pontos de vista, e cada situação é pensada de modo a extrair-se princípios gerais (para todos). Um indivíduo situado nesse nível, explica Kohlberg (1992), compreende e aceita as regras da sociedade na sua globalidade, mas apenas porque primeiramente aceita determinados princípios morais gerais que lhe estão subjacentes. De fato, os princípios morais podem transcender figuras de autoridade ou até as normas ou valores de uma sociedade particular. Conforme ilustram Carmino, Moraes e Galvão (2006), o indivíduo poderá entrar em conflito com as regras da sociedade, julgando uma situação com base em determinado princípio e não na convenção social. Por outras palavras, os princípios morais são internalizados e tornam-se individualizados. Dentro do nível 3, existem os estágios 5 e 6 .

No estágio 5, Kohlberg (1992) relaciona o discurso com o comportamento moral como aquilo que expressa a vontade da maioria ou maximiza o bem-estar social. A sociedade, explicam Rest et al. (1999), deve basear-se em um contrato social aceito livremente pelas pessoas e em que sejam respeitados direitos fundamentais como a vida e a liberdade individual, e utilizados processos democráticos para alterar as leis e melhorar a sociedade. Isso significa, enfatiza Bataglia (2001), que as pessoas têm consciência de que os indivíduos defendem diferentes valores e opiniões, e de que grande parte dos valores e das regras são específicos de determinado grupo, embora devam ser normalmente respeitados a fim de se garantir a imparcialidade ou isenção, até porque fazem parte do contrato social. No entanto, Kohlberg (1992) cita que determinados valores e direitos não específicos, como a vida e a liberdade, têm de ser forçosamente defendidos nos discursos dos indivíduos em qualquer sociedade, independentemente da opinião da maioria.

No estágio 6, Kohlberg (1992) ressalta que está incluído um número muito reduzido de indivíduos. O comportamento que é considerado correto e moral é controlado por um ideal interiorizado, que é independente das reações dos outros, mas que respeita sempre os princípios universais (exemplo: igualdade de direitos, dignidade e justiça). Nesse estágio, cada pessoa é compreendida como um meio e nunca como um fim. A definição daquilo que é correto ou errado, relembram Carmino, Moraes e Galvão (2006), é feita com base em princípios éticos que são adotados por cada indivíduo, sendo que se dá preferência pelo cumprimento do dever e pela consciência de cada indivíduo. Esses princípios não são regras concretas, avalia Bataglia (2001), mas orientações que cada indivíduo considera justas e que podem ser aplicadas em todas as situações, sendo que estão relacionadas com a concepção de justiça, direitos humanos e igualdade de oportunidades.

Para concluir, Carmino, Moraes e Galvão (2006), Bataglia (2001) e Kohlberg (1992) compreendem que, sob o ponto de vista da Ciência, é indispensável uma reflexão: até que ponto é eticamente aceitável que as pessoas veiculem ideologias sem que elas se deem conta disso? Seria importante uma análise precisa a fim de discernir o que são os conteúdos ideológicos de nossos 
discursos para, então, decidir se há um desejo ou não de propagar as ideologias veiculadas e enraizadas por eles.

\section{ATITUDES DOS PROFESSORES DE CIÊNCIAS EM SITUAC̣ÕES DE TENSÃO}

Pietrocola (2004) apresenta a ciência que não desvela truísmos. Ao contrário, faz parte da grandeza e da beleza da ciência o fato de podermos aprender, através de um momento de tensão e de investigações conduzidas pelo espírito crítico (BACHELARD, 2001), que o mundo é inteiramente diverso daquilo que chegamos a imaginar, até que a nossa intuição e imaginação sejam reformuladas pela refutação de teorias anteriores. Nesse contexto, a ilusão das verdades absolutas passou a aceitar mais as afirmações relativas, as dúvidas e incertezas como componentes primordiais do pensamento científico, abrindo, com isso, os limites do seu objeto e permitindo que temas envolvendo a ética ganhassem força no meio da comunidade científica.

Quanto ao ensino de Ciências, face às mudanças detectadas ao longo da história, Moreno (2008) destaca que tal processo formal não pode ficar alheio a essa nova forma de conceber a ciência. Para Delizoicov e Angotti (2006), as mudanças a serem feitas na escola devem seguir o mesmo sentido dessa nova ideia de ciência, ou ela correrá o risco de preparar os estudantes para um futuro inexistente, muitas vezes de forma inadequada para as necessidades da sociedade na qual terão de viver. Com isso, muito do espírito de uma ciência com a visão arcaica, cujas lutas no campo do conhecimento impunham a razão do mais forte, chegando à eliminação física do adversário, ainda perdura na ciência atual e no seu ensino nas escolas.

Como antídoto a essa realidade, o professor apresenta-se como agente humano que na sala de aula precisará decidir, e a sua decisão pode modificar a existência dos outros e do mundo (DELIZOICOV; ANGOTTI, 2006). Uma decisão, portanto, que não ocorre sem sofrimento, sem tensão, pois exige a escolha em uma situação repleta de ambiguidades e dilemas, com diferentes respostas possíveis e discursos ideológicos (BICUDO, 2007). Assim sendo, o professor, ao assumir uma perspectiva de questionamento e crítica, fornece um passo importante na constituição de interfaces entre o ensino científico e a abordagem de questões éticas na escola (DELIZOICOV; ANGOT'TI, 2006; OLIVEIRA, 2006; DELORS, 2006).

Diante desse pressuposto e da complexidade do tema, a nossa preocupação limita-se, a partir de agora, a assuntos relacionados ao ensino de Biologia, dentre os quais o tema "transgênicos" foi escolhido porque é gerador de polêmica há mais de três décadas. Reportamos ao caso "troca troca milho", um programa brasileiro da década de 80 que avaliou a não rentabilidade e produtividade de produtos transgênicos. Mais recentemente acompanhamos novas discussões (CACHAPUZ; GIL-PÉREZ; VILCHES, 2005; GRIFFITHS, 2008; PEDRANCINI, 2008) colocadas na mesa de debates das mais variadas classes e grupos sociais. Consumir os trangênicos ou não? Incentivá-los ou não? São essas as perguntas frequentes nessas discussões. 


\section{AS SITUAC̣̃̃ES DE TENSÃO ENTRE ACEITAÇÃO E NEGAC̣ÃO NO USO DOS TRANSGẾNICOS}

O confronto entre aceitação e negação no uso dos transgênicos gera controvérsias e muitos debates. Mesmo no interior desse binômio, as divergências ocorrem. No entanto, as maiores divergências acerca do tema aparecem entre ciência e ética. Na perspectiva da ciência, não são raras as citações, em publicações científicas, de aceitação e negação no uso dos organismos híbridos, entendidos aqui como aqueles provenientes do cruzamento de espécies diferentes.

No exemplar de 29 de outubro de 2003, a revista Veja exemplifica bem o clima proveniente da polêmica transgênicos: para ou continua, com os seguintes dizeres: "Poucos temas são discutidos num clima de tanta paixão e irracionalidade quanto a transgenia. Compreende-se. Os transgênicos representam uma ruptura cultural sem precedentes na história da humanidade, e um desafio à crença segundo a qual o homem pode pagar caro se mexer naquilo que Deus fez. O acerto de contas viria em forma de uma vingança da natureza, como aconteceu no caso da vaca louca. (...) No caso dos transgênicos, as pessoas, mesmo sem ter ideia precisa do que significam essas mutações, adotam uma postura contra ou a favor, em geral sem grandes reflexões. De um lado concentram-se os que tendem a aprovar os avanços científicos e os benefícios que trazem para a humanidade e para os fabricantes dos novos produtos que saem dos laboratórios. De outro, estão os que reprovam, principalmente ambientalistas e, de maneira geral, militantes de partidos de esquerda” (PARTURY; FELIPE; SCHELP, 2003, p. 32).

Fiorillo (1999, p. 61) entende que "o uso dos transgênicos é positivo, mas o desconhecimento dos malefícios que os produtos transgênicos podem causar aos seres humanos é um aspecto negativo a ser levado em conta". Sirvinskas (2003) só enxerga desvantagens no cultivo das sementes transgênicas. $\mathrm{O}$ autor entende que as sementes poderiam transmitir seu material genético a outras espécies, gerando "superpragas". Os herbicidas, por fim, inoculados nas sementes modificadas, poderiam afetar animais e insetos importantes ao equilíbrio do meio ambiente.

Quanto à relação de consumo, Machado (2003) reforça que o consumidor precisa ser lembrado e ter sempre em mente que os produtos que está comprando são geneticamente modificados, optando, então, pela sua escolha ou não. Já no que tange ao meio ambiente natural, um aspecto importante diz respeito à possibilidade de surgimento de certos vírus e moléculas e, ainda, de prejuízos ao meio ambiente caso haja transferência incontrolada de genes.

Os alimentos oriundos de cultivos transgênicos poderiam prejudicar seriamente o tratamento de algumas doenças de homens e animais. Isto ocorre porque muitos cultivos possuem genes de resistência antibiótica. Se o gene resistente atingir uma bactéria nova, pode conferir-lhe imunidade ao antibiótico, aumentando a lista, já alarmante, de problemas médicos envolvendo doenças ligadas a bactérias imunes" (MACHADO, 2003, p. 931). 
Na perspectiva da ética, a descoberta da possibilidade de transferir genes de organismos de uma espécie para outra representa, hoje, uma das mais intrigantes ferramentas de que o homem dispõe para desenvolver tecnologias e organismos a partir da ruptura de barreiras que existem entre organismos de diferentes espécies em condições naturais.

Altieri (2008) apresenta um conjunto de razões pelas quais a biotecnologia não garantirá a segurança alimentar, não protegerá o ambiente e não reduzirá a pobreza no terceiro mundo. Além disso, nada se sabe a respeito da possibilidade de efeitos da ingestão continuada de transgênicos e/ou derivados a médio e longo prazo sobre a saúde humana. No entanto, circunstâncias econômicas poderão impor a toda a população a ingestão desses alimentos.

Lappé e Bailey (2000) entendem que a realidade é que a promessa da biotecnologia não se cumpriu na área de alimentos, uma vez que os produtos que hoje chegam ao mercado não trazem qualquer tipo de vantagem em qualidade para o consumidor e tampouco são mais baratos. As possíveis vantagens para o produtor também são questionáveis. Transgênicos não são mais produtivos do que os não transgênicos.

Ellstrand (2003) defende que os cientistas são pesquisadores, professores e cidadãos. Como pesquisadores, eles têm a responsabilidade pela ciência que sai dos seus laboratórios. Como professores, eles têm a responsabilidade de comunicar o que aprendem da ciência para a sociedade que os mantém, abrindo as portas do conhecimento. E como cidadãos, eles têm a responsabilidade de ouvir o que a sociedade pensa sobre o que eles aprendem e ensinam. Machado (2003), Singer (2002), Fourez (1995), Cachapuz, Gil-Pérez e Vilches (2005), Griffiths (2008) entendem que devemos abrir essas portas cuidadosamente, nunca deixando nossa ciência ir adiante de nossa ética. Ciência e tecnologia não são inerentemente morais. A responsabilidade de colocar moralidade nelas pertence a cada cidadão.

Nesse sentido, apresentamos os resultados parciais de uma pesquisa desenvolvida com professores de Ciências, a partir das seguintes questões de investigação: "Quais as concepções dos professores sobre ética, abordagem da ética no ensino de ciências e transgênicos?”, “Quais os discursos apresentados pelos professores para a prática da ética em sala de aula?”, "Que atitudes são fomentadas pelos professores no tratamento de temas que caracterizam tensão?”.

\section{METODOLOGIA DE COLETA DE DADOS}

Os sujeitos investigados são seis professores de Ciências atuantes na rede estadual de Ensino de Tijucas. Desse conjunto, todos têm graduação em Ciências Biológicas e pós-graduação (lato sensu). Dentre os professores, dois lecionam na rede há mais de quinze anos.

Para identificar e analisar as concepções que os professores de Ciências possuem sobre a natureza da ética, seus discursos ideológicos e atitudes em situações 
de tensão na abordagem do tema transgênicos, utilizamos como instrumentos de coleta de dados a Técnica de Complemento, que consiste na apresentação de um estímulo escrito para ser completado com palavras, podendo ser uma palavra, uma sentença, um parágrafo, uma imagem (VERGARA, 2008). Pela Técnica de Complemento objetivamos identificar motivações, crenças, discursos, sentimentos que dizem respeito ao objeto estudado. Em nosso caso, solicitamos aos professores que completassem sentenças.

Também utilizamos entrevistas semiestruturadas com os seis professores de Ciências. Bauer e Gaskell (2003) compreendem que toda pesquisa com entrevistas caracteriza-se como um processo social, uma interação ou um empreendimento cooperativo, em que as palavras são o meio principal de troca. Não é apenas um processo de informação de mão única passando do entrevistado para o entrevistador. Ao contrário, ela é uma interação, uma troca de ideias e de significados, em que várias realidades e percepções são exploradas e desenvolvidas. A entrevista semiestruturada possui a função de complementar as informações que são trocadas e ampliar os ângulos de observação, possibilitando uma maior aproximação da perspectiva dos sujeitos, na tentativa de conhecer suas percepções, aspirações, vontades e atitudes, ou seja, os significados atribuídos à realidade e às suas próprias ações (LÜDKE; ADRIANO, 2006).

A entrevista semiestruturada contém os temas que serão abordados, mas a ordem e a forma como eles serão trabalhados são livres, havendo um guia geral para a entrevista, com algumas perguntas que serão introduzidas na conversa, e outras que podem ser acrescentadas, caso as que já foram abordadas pelo entrevistador não sejam respondidas (SALVADOR, 2002). Essa etapa foi gravada em áudio e as respostas foram transcritas, posteriormente, com a autorização consciente e assinada dos participantes de nossa investigação. Foi garantida a privacidade de cada participante na divulgação dos resultados para que eles pudessem expor posicionamentos pessoais.

\section{METODOLOGIA DE ANÁLISE DOS DADOS}

A etapa das análises consiste em um importante momento da pesquisa e tem como principal objetivo "procurar sentidos e compreensão. O que é realmente falado constitui os dados, mas a análise deve ir além da aceitação deste valor aparente. A procura é por temas com conteúdo comum e pelas funções destes temas" (GASKELL, 2008, p. 84).

A partir de três unidades de análise, previamente estabelecidas, organizamos as respostas dos seis professores, que doravante serão denominados P1, P2, P3, etc., procurando identificar relações entre as unidades, com a intenção de compreender melhor o que eles pensam e como organizam suas ações com vistas à abordagem de temas que geram tensão, neste caso específico, a ética e o uso de transgênicos. As unidades ficaram assim organizadas: a natureza da 
eticidade, discurso ideológico e desenvolvimento moral e atitudes dos professores de Ciências em situações de tensão.

Antes de iniciarmos a entrevista, acontecia uma conversa informal com cada professor, com o intuito de diminuir o nervosismo que a própria situação gerava. No decorrer da entrevista, procuramos assumir uma postura de interesse, atenção e compreensão pelas respostas do professor, permitindo que ele se sentisse à vontade para responder e falar livremente sobre os seus pontos de vista. As respostas foram gravadas em áudio e transcritas posteriormente.

A terceira e última etapa foi identificar as atividades desenvolvidas pelos professores, para a apresentação do tema transgenia. Para tanto, também utilizamos a Técnica de Complemento, dividida em duas partes, sendo a Técnica de Complemento "A" para existência de abordagem de questões éticas no ensino de Ciências, e a "B" para a descrição de uma atividade de iniciação científica.

\section{RESULTADOS E ANÁLISES}

A pesquisa teve início no segundo semestre de 2013 e aconteceu em seis escolas da rede estadual de Tijucas, Santa Catarina. Estabelecemos, como objetivo, analisar a concepção dos professores em relação à natureza da ética, discursos ideológicos e atitudes dos professores em situação de tensão na apresentação do tema transgenia.

\section{A concepção da natureza da ética}

Entendemos que a concepção de ética dos professores de Ciências influenciará, pelo menos em parte, um conjunto de entendimentos, decisões e ações que serão planejadas e trabalhadas em sua prática docente. O "participar da ética" pressupõe, por parte dos professores, encaminhamentos e decisões sobre como eles compreendem a ética, para a abordagem de questões éticas no ensino de Ciências, bem como a maneira como mobilizam os estudantes no desenvolvimento de discursos ideológicos durante o seu processo de construção do conhecimento. Apresentamos, em síntese, concepções de ética dos professores de Ciências, organizadas em três categorias, de acordo com suas respostas: (1) a ética como comprometimento (P1 - P3 - P5 - P6), P5 afirma que "é estar comprometido com os direitos e deveres, comprometido com os ideais de um grupo. Ter respeito com o outro"; P1 afirma que "são os valores que primam por um bom andamento do grupo que os exercita, é se comprometer, respeitar e valorizar a classe à qual se pertence"; (2) a ética como valores e princípios (conforme P2, "para mim são valores e princípios que o indivíduo possui e que por meio deles sabe distinguir certo, errado e saber por que assim o fez"); e (3) a ética como moral individual ou de grupo (segundo P4: “acho que é a postura de uma pessoa em relação à outra ou do governo em relação ao povo, quando se trata de dignidade de vida, do respeito às pessoas como cidadãs, valorizando-as pelo que elas são, não pelo que elas têm”). 
Percebe-se que existem diferentes concepções de ética, entretanto, os professores mencionaram aspectos importantes: compromisso com a abordagem do tema ética no ensino de Ciências, com o grupo, presença de valores e princípios, conforme P1 e P2. Porém, algumas respostas parecem vagas, como a apresentada por P4: "Postura de uma pessoa". Os professores P3 e P5 apresentaram uma importante característica da ética: o tratamento humano, ideia defendida por Fourez (1995), que entende que a ética como estudos dos juízos de apreciação referentes ao tratamento humano, considera outras instâncias além do binômio bem e mal, correto e incorreto, como discussões da conduta do ser humano com temas que despertam controvérsias, como clonagem, biotecnologia, transgênese, entre outros. P6 menciona que a ética é adquirida a partir da prática, seguindo bons exemplos, e que está em conformidade com o grupo social. Vall (2000) defende que os hábitos e comportamentos aceitos são frutos do espaço, do tempo e da localidade, envolvendo costumes muitas vezes enraizados por determinada cultura, deixando explícita a condição situacional da ética.

P1, P5 e P6 mencionaram a ética como caráter coletivo, que deve estar implícito em seu conceito, porém, a referência está atrelada às pessoas "(P1) com quem convivemos”; (P5) “para com o próximo”. Vázquez (2002) e Zajdsznajder (1999) comentam que, muitas vezes, as pessoas encontram-se desobrigadas de serem éticas com indivíduos com os quais não se relacionam.

Valls (2000) defende que há, atualmente, uma superficialidade na questão mais ampla da universalidade de valores. Assim, pode-se afirmar que os professores não têm clareza da obrigatoriedade da ética para com aqueles dos quais não se sabe o nome, o local e a data de nascimento; não avaliam a ética como fator preponderante para manter a dignidade dos indivíduos em qualquer lugar do mundo civilizado e o respeito para com aqueles que não conhecem a "civilização".

As constatações acima evidenciam que a ética, enquanto campo de reflexão coletiva e individual, está longe de uma concepção mais homogênea e trabalhada no grupo dos professores pesquisados. Segundo Singer (2002), há um distanciamento bastante grande com relação a uma concepção de ética em uma perspectiva da conduta e do tratamento humano. Como foi possível perceber, as concepções dos professores de Ciências são bastante incipientes, ou seja, não são produto de uma reflexão crítica, coletiva e rigorosa das condições que permeiam a realidade social, política e econômica do ponto de vista da ética.

\section{Os discursos ideológicos e o desenvolvimento moral no ensino de transgênicos}

Acreditamos que o entendimento a respeito do discurso ideológico e do desenvolvimento moral adotado pelos professores de Ciências durante o ensino de transgênicos é importante para a compreensão de como a ética é construída e como ela se desenvolve em sua prática pedagógica. Para Fourez (1995), o professor apresenta-se como mediador entre o sujeito e o objeto do conhecimento, como potencial para construir um ambiente de decisões ou atitudes repleto de ambiguidades e dilemas, com diferentes respostas possíveis, pois são muitos e 
diversificados os aspectos envolvidos em uma sala de aula de Ciências. No que diz respeito ao entendimento sobre discurso ideológico e desenvolvimento moral, foi possível identificarmos duas categorias.

A primeira delas é o posicionamento egocêntrico (P1, P4). Conforme P1: "Eu acho que muitas pessoas não têm direito a opinar sobre temas polêmicos, como por exemplo, os transgênicos. Porque são ignorantes com relação ao tema e ficarão apenas no senso comum”. Para P4: “as pessoas aprendem a formar suas opiniões, seus critérios de julgamento por meio de diversos veículos de comunicação, em especial a internet que estabelece o ritmo do progresso, impõe sua presença em todas as dimensões da vida e se converte em condutora dos rumos da civilização”. Para Kohlberg (1992), o indivíduo que apresenta um raciocínio moral egocêntrico e segue as normas pensando em interesses próprios é considerado individualista. A mudança moral, explicam Rest et al. (1999), alicerçada em deveres para a moral baseada em direitos, é uma questão de desenvolvimento individual (do pré convencional para o pós convencional).

Essa primeira categoria confirma os estudos de Kohlberg (1992) de que a maioria das pessoas se incluem no nível pré convencional. Muitos adultos ainda continuam pensando e agindo conforme suas convicções e não pelos parâmetros do nível convencional. P4 afirma, além disso: "acredito que temas polêmicos devam ser debatidos por nós, professores e cientistas. A sociedade, em geral, é corrompida por instituições com intenções deturpadas". P1 afirmou que "como cidadãos, vivenciamos hoje um momento distinto da nossa história quando comparamos com as décadas de 50 e 60, e é de acordo com as minhas respostas às novas condições que se apresentam no uso de transgênicos e com o grau de consciência e de conhecimentos que continuarei a decidir sobre minhas escolhas". Kohlberg (1992) relembra que um posicionamento individualista de um indivíduo em seu discurso, demonstra sua incapacidade de preocupação com os valores e princípios universais, como o direito à vida e à liberdade. $\mathrm{O}$ indivíduo não tem noção da regra, nem consegue avaliar as intenções, sendo que para ele a gravidade de uma situação está relacionada com as consequências que esta pode trazer.

A segunda categoria é o posicionamento nas convenções e regras socioambientais (P2 - P3 - P5 - P6). P2 afirmou que "eu alerto e promovo aos meus estudantes a análise e discussão no uso dos alimentos transgênicos na atualidade, uma questão que não pode ser deixada de lado". P2 ainda relembrou que "com a chegada desses produtos às prateleiras dos supermercados e levando-se em consideração o direito de informação, muito se discutiu sobre a necessidade de avisar aos consumidores qual era a real procedência do que eles estavam consumindo e suas consequências no fator social e ambiental". Altieri (2008) enfatiza que estamos vivenciando um período de grande modificação na forma de produção de alimentos e outras matérias-primas para a sociedade humana.

P3 citou que "a realidade é que a promessa da biotecnologia não se cumpriu na área de alimentos, mas é fato que os transgênicos já fazem parte da alimentação de muitos brasileiros, honrando com uma das funções essenciais, que é a busca da 
erradicação da fome”. Lappé e Bailey (2000) entendem que as possíveis vantagens para o produtor também são questionáveis. Transgênicos não são mais produtivos do que os não transgênicos Trata-se muito mais de uma corrida comercial. Sobre os discursos desses professores, Kohlberg (1992) os descreve como a necessidade de definir normas para o estabelecimento de um sistema amplo de cooperação, utilizando da lei formal para a estabilização de expectativas e envolvimento entre as pessoas que não são familiares, íntimas ou não se conhecem. A tal comportamento, Kohlberg (1992) classifica como convencional de estágio 3, ou seja, o indivíduo cumpre com aquilo que é devido e esperado dele na sociedade.

P5 e P6 apresentam praticamente o mesmo discurso, afirmando, em linhas gerais, que "é necessário, em sala de aula, conversar com os estudantes sobre instituições isentas que deverão desenvolver projetos de pesquisa de médio e longo prazo para analisar as questões sobre transgenia. Cabe, em sala de aula, promover um ambiente de discussão, criticidade e diálogo. No entanto, é preciso também respeitar as leis e regras que regem nossa sociedade". Sobre esse posicionamento Kohlberg (1992) entende que existe, nesse tipo de discurso, uma consciência inicial de que os interesses coletivos são mais importantes do que os individuais. Há perspectiva moral à manutenção da ordem social e daquilo que foi proposto pelas autoridades, sendo que, para tanto, todos devem colaborar com a organização social e com as instituições. Para Garrafa (2010) e Gil-Pérez et al. (2005), o maior objetivo e desafio do ensino de Ciências é fazer com que o indivíduo se apodere do conhecimento, criando, assim, sujeitos altamente críticos, questionadores e éticos. Os avanços na área científica e tecnológica têm colocado a humanidade em caminhos pouco imagináveis. Se por um lado ela possibilita a conquista da melhoria da qualidade de vida, por outro cria desacordos que precisam ser controlados para que não haja um desequilíbrio e para que não comprometa o bem-estar da vida humana no planeta (SOLOMON, 2010).

\section{As atitudes dos professores investigados em situações de tensão na abordagem do tema transgênicos}

$\mathrm{Na}$ trajetória da pesquisa, colocamos em discussão algumas possibilidades nas relações éticas em sala de aula, mais especificamente nas atitudes inerentes aos assuntos polêmicos do ensino de ciências e suas respectivas consequências no desenvolvimento moral dos estudantes. O enfoque ficou restrito ao seguinte problema: quais atitudes estariam configuradas nas representações dos professores de Biologia ao ensino de transgênico, diante de questões éticas geradas pelos momentos de tensão, e quais implicações no desenvolvimento moral dos estudantes? Poderíamos esperar atitudes múltiplas ou unívocas? Mais do que respostas, buscamos a compreensão das atitudes e representações, ou seja, os processos subjacentes de sua construção e as interações histórico-sociais correspondentes.

A respeito das atitudes em situações de tensão na apresentação do tema transgênicos, identificamos duas categorias: (1) o apoio ao uso do transgênico (P1 - P3 - P6). P1, por exemplo, afirmou que "os transgênicos enquanto sementes 
modificadas, mais resistentes, que não possibilitam reprodução, são importantes porque são resistentes a pragas, aumentando a produção industrial". Sobre esse pensamento, Fiorillo (1999) entende que o uso dos transgênicos tem seu aspecto positivo, mas o desconhecimento por parte da população dos malefícios que os produtos transgênicos podem causar aos seres humanos é, ainda, um aspecto preocupante a ser levado em conta. P3, em seu discurso, apontou que "enquanto organismo (planta, animal ou micro-organismo) que sofreu transferência de um gene ou mais, escolhido, identificado e controlado com precisão e com função definida, pode ser usado para o desenvolvimento de vacinas, remédios, produção de tecidos, melhoramento vegetal". Sobre o posicionamento de P1 e P3, Aragão (2003) defende que a maioria dos professores de Ciências Naturais não consegue, ainda, estabelecer relações significativas em torno da temática transgênicos. Mesmo os professores conceituando transgênicos de forma científica, ou seja, que um organismo transgênico pode ser tanto um micro-organismo, planta ou animal, em cujo genoma foi inserido um gene de outro organismo, esses profissionais têm uma visão fragmentada acerca dos transgênicos, o que leva a um corte da realidade, perdendo de vista a totalidade. Por sua vez, P6 relatou "que o uso de transgênicos é um grande avanço para a humanidade, que poderá contar com safras bem aproveitadas, com menos perda e mais qualidade. Não acho que seja uma ameaça". Para Moscovici (2004), a atitude de P6 revela que quando o conhecimento científico penetra na vida cultural de uma sociedade, surgem controvérsias intelectuais e oposições em diferentes modos de pensar.

Outra categoria que emergiu na entrevista foi: (2) transgênico enquanto ameaça à saúde e à biodiversidade (P2 - P4 - P5). P2, em seu relato, explicou que "os transgênicos são um perigo à saúde e à biodiversidade. É uma semente feita em laboratório, que eles cruzam com micróbios, bactéria e vírus, que causam doenças, podendo este infectar o organismo do homem causando câncer nas pessoas". P4 afirmou que "os transgênicos são uma ameaça à saúde e à biodiversidade, afinal de contas, onde estão as pesquisas que provam o contrário? Por que não plantam na Europa e EUA? Quem garante que não aparecerão pragas tão resistentes que além de acabarem com os transgênicos acabarão com as demais plantas?”. Quanto às representações dos professores P2 e P4, que consideram os alimentos transgênicos uma ameaça à saúde e à biodiversidade, é importante salientar que, sem dúvida nenhuma, muitos desses temores são compreensíveis e fundamentados, e outros são especulativos (FOUREZ, 1995). No entanto, a controvérsia, representada pelos diversos setores da sociedade, contribui para enriquecer e democratizar a ciência. Controvérsia, aqui, é entendida como a capacidade de acompanhar e expor um debate acerca de temas que ainda não estão assegurados científica e tecnicamente. (RIECHMANN, 2007). Por fim, P5 citou que "não considero os transgênicos uma solução para os problemas da fome, pois não conseguem produzir plantas cada vez melhores, possibilitando uma produção de alimentos em menos tempo, além de poder proporcionar situações de risco à vida humana”. Fourez (1995), Gil-Pérez et al. (2005), Griffiths (2008) e Pedrancini (2008) compreendem, sobre o 
posicionamento de P5, que, para um professor de Ciências, a presença de lacunas acerca dos conhecimentos científicos básicos ainda não permite uma maior ação reflexiva e crítica destes em relação aos avanços científicos e tecnológicos, de forma que o conhecimento se torna muito fragmentado, ou seja, não está organizado e estruturado, comprometendo o seu entendimento e impedindo que os professores se posicionem de forma autônoma na sociedade.

\section{Atividades na apresentação do tema transgenia}

Com o intuito de aprofundar as concepções dos professores, solicitamos que eles apresentassem atividades sobre o tema transgenia, descrevendo detalhadamente seus objetivos, como a atividade era organizada e desenvolvida e quais as atitudes e habilidades vivenciadas pelos estudantes. Entre as atividades descritas, apresentamos um exemplo relacionado ao tema "horta e transgênicos: uma relação de cautela", de acordo com o quadro 1.

Quadro 1: Atividades desenvolvidas pelo professor P6 para apresentação do tema transgênicos.

\section{Atividade apresentada por P6: "Horta e transgênicos: uma relação de cautela"}

OBJETIVO(S): “Plantar sementes geneticamente modificadas. Observar o comportamento das folhas; plantar sementes não geneticamente modificadas. Observar o comportamento das folhas.

Evitar o uso de veneno nas duas plantações. Verificar o gosto dos alimentos nas duas situações.

ORGANIZAÇÃO E DESENVOLVIMENTO DA ATIVIDADE: “Observação local, conversação

(questionamentos); pesquisa e registros, conversação com quem estuda sobre; conclusão prática, elaboração de um folder".

DESENVOLVE ATITUDES/HABILIDADES? QUAIS? “Creio que sejam desenvolvidas as habilidades de interpretação, de registros, atitude crítica. Atitudes: mudança de hábitos em relação ao meio ambiente, percepção da vida natural, posicionamento crítico ao uso de transgênico".

Fonte: (Dados primários, 2014)

Podemos perceber que P6 descreve ações importantes, como a observação e a pesquisa, mencionando procedimentos relacionados ao tema, como: "observar os alimentos orgânicos e modificados geneticamente" e "pesquisar alternativas de recursos naturais que sejam viáveis à plantação de alimentos". P6 não apresentou os questionamentos que mobilizaram a investigação, porém, associou-os à observação do local e às conversas, o que possibilitaria, a partir daí, o desenvolvimento, pelos estudantes, de ações específicas do "fazer ciência e agir eticamente": problematizar, planejar etapas da investigação, coletar informações e organizar formas de registros, discutir dados, inferir, concluir, comunicar, visando a uma compreensão mais aprofundada do fenômeno.

No que diz respeito às atitudes e habilidades, P6 citou a interpretação de registros, a crítica, a mudança de hábitos em relação ao meio ambiente e a percepção da vida natural. No item "organização e desenvolvimento da atividade", citou a observação e os registros, e a "conversação com quem estuda sobre o tema, referindo-se a um especialista”, mas não especificou o que exatamente isso 
significa e como aconteceu. Quando solicitado para descrever como organizou e desenvolveu a atividade, P6 resumiu-a na montagem, preparação e manutenção de uma horta pelos estudantes. Os estudantes apenas montam a horta, semeiam e tentam mantê-la em ordem. Lembramos que uma aprendizagem significativa e duradoura é facilitada pela participação dos estudantes na construção do conhecimento científico que está sendo trabalhado, de acordo com Gil-Pérez et al. (2005). Ressaltamos que os problemas associados à horta e ao uso de sementes transgênicas podem ser pontos de partida muito interessantes para introduzir os estudantes no processo, uma vez que eles necessitam ser continuamente desafiados na identificação e na resolução problemas, bem como na construção de metodologias para resolvê-los. Evidenciamos que, nesse processo, o registro e a organização dos dados são considerados uma etapa particularmente importante.

\section{CONSIDERACְÕES FINAIS E CONTRIBUICְÕES}

Ao finalizarmos este trabalho, podemos tecer algumas considerações a respeito das concepções dos professores de Ciências sobre transgênicos e os processos de educação ética mais significativos nas escolas da rede estadual da cidade de Tijucas.

No que diz respeito ao entendimentos acerca da temática transgênicos, constatou-se que a maioria dos professores de Ciências apresentam um domínio de representação que engloba, sobretudo, a ideia de que os transgênicos são alimentos geneticamente modificados, ou seja, plantas comestíveis cuja aplicabilidade e benefícios voltam-se exclusivamente à agroalimentação, cujos perigos podem englobar o câncer, alergias e infecções. Entretanto, ao considerarem apenas uma parte dessa realidade, eles deixam de compreender as relações possíveis de uma totalidade. Tais relações se revelam no avanço da Biotecnologia, cuja aplicabilidade está presente em diversas áreas do conhecimento, com benefícios já comprovados como produção de hormônios, antibióticos, interferon, cultura de órgão animal que não provoque rejeição, etc.

Apesar de os professores apresentarem certo posicionamento ético referente ao uso de transgênicos, sua visão sobre a aplicabilidade e os benefícios acerca dessa tecnologia ainda é restrita e fragmentada, o que impede que haja debates críticos sobre um tema tão complexo. Além disso, a maioria dos professores considerou que o consumo de alimentos transgênicos pode trazer malefícios, mas que essa tecnologia pode solucionar o problema da fome no mundo. Parece contraditório, porém, há um sentido nisso, já que no Brasil, onde 13,7 milhões de pessoas passam fome e outros 40 milhões se alimentam de forma insuficiente ou desequilibrada, um apelo da mídia a favor de grupos específicos tem bastante força e receptividade entre muitas pessoas que não conseguem fazer uma leitura crítica dos meios de comunicação.

Portanto, as representações dos professores no tocante a esse tema são midiáticas e ideológicas. Diante dessas representações que refletem o pensamento 
dos professores, reafirma-se, aqui a necessidad,e da qualificação continuada para que eles possam se posicionar de forma autônoma e crítica na sociedade. A qualificação deve ser voltada para a atualização dos conteúdos científicos acerca dos temas na área da Biotecnologia e nas outras áreas do conhecimento. É importante, também, a introdução de cursos para o reconhecimento dos artifícios (processos e técnicas editoriais) da mídia, para que esses profissionais possam fazer uma leitura crítica dos meios de comunicação, se posicionem de modo ético e apresentem aos estudantes valores morais universais, e não particulares.

No tocante à etica, não há dúvidas de que questões de moral e de responsabilidade social inevitavelmente fazem parte da educação em Ciência, deixando professores expostos constantemente ao tratamento de valores diversos (LACAZ-RUIZ; CASTRO, 2004). Por isso, o ensino de Ciências deve ser projetado para um processo no qual todo o campo de ação do desenvolvimento pedagógico entre estudantes, professores, conteúdos, metodologias, etc. apresente tendências éticas nas suas relações. Nesse caso, exigências mais complexas são necessárias. É no ensino de Ciências que também deve prestar-se ao estímulo do desenvolvimento moral dos estudantes e não apenas dirigir-se à intelecção, ao cognitivo, sobretudo porque essa disciplina trabalha com muitas possibilidades de conteúdos polêmicos, sendo frequentemente cenário para discussões éticas e morais.

Para finalizar, alerta-se para a necessidade de um número maior de investigações sobre a temática apresentada por este artigo. Além de preencher lacunas existentes, tais pesquisas contribuiriam para dar maior consistência aos rumos tomados pelo ensino de Ciências, especialmente nos dias atuais, com as inserções e discussões cada vez mais crescentes de temas polêmicos em praticamente todas as áreas do conhecimento, sobretudo na ciência.

\section{REFERÊNCIAS}

ALTIERI, M.A. The environmental risks of transgenic crops: an agroecological assessment. AgBiotech news and Information, 2008.

ARAGÃO, F. J. L. Organismos transgênicos: explicando e discutindo a tecnologia. Barueri, São Paulo: Manole Ltda, 2003.

BACHELARD, G. A formação do espirito científico: contribuição para uma psicanálise do conhecimento. 3. ed. São Paulo: Contraponto, 2001.

BATAGLIA, P.U.R. A construção da competência moral e a formação do psicólogo. 2001. 102 f. Tese (Doutorado em Psicologia Social) - Universidade de São Paulo, São Paulo, 2001.

BAUER, M.W. e G. Gaskell. Pesquisa qualitativa com texto, imagem e som: um manual prático. Petrópolis, RJ: Vozes, 2003.

BICUDO, M. A. V. Fundamentos éticos da educação. São Paulo: Autores Associados/ Cortez, 2007.

BIZZO, N. Ciências: Fácil ou difícil. 2ª ed., 10ª impressão. São Paulo: Ática, 2008.

BRASIL. Secretaria de Educação Fundamental. Parâmetros Curriculares Nacionais: terceiro e quarto ciclos do ensino fundamental; Ciências. Brasília: MEC/SEF, v. 4, 1998. Disponível em: < http/ portal.mec.gov.br/seb/arquivos/pdf/ciencias.pdf.> Acesso em 9 dez. 2013.

CACHAPUZ, A. GIL-PÉREZ, D., VILCHES, A. A necessária renovação do ensino das ciências. São Paulo: Cortez, 2005. 263 p. 
CARMINO, C.; MORAES, R.; GALVÃO. Diferenças de gênero no raciocínio moral. In: SIMPÓSIO NACIONAL DE PSICOLOGIA SOCIAL E DO DESENVOLVIMENTO, 6., 2006. Vitória, ES. Textos completos.Vitória, ES: SNP, 2006. p. 101 - 109

CARVALHO, A. M. P de. Introduzindo os alunos no universo das ciências. In: Wethein, J \& Cunha, C. da. (org). Ensino de Ciência e Desenvolvimento: o que pensam os cientistas. São Paulo: Unesco, 2009. Disponível em: <http://unesdoc.unesco.org/por.pdf>. Acesso em: 9 de maio de 2013.

COSTA, C. Introdução: o Conhecimento como característica da humanidade. In: Sociologia. 3. ed. São Paulo: Moderna, 2009.

DELIZOICOV, D.; ANGOTTI, J. A. P. Ensino de Ciências: fundamentos e métodos. São Paulo: Cortez, 2006.

DELORS, J. Educação um tesouro a descobrir: Relatório para UNESCO da Comissão Internacional sobre educação para o século XXI. 10. ed. São Paulo: Cortez, 2006.

ELLSTRAND, N.C. Going to "Great Lengths" to Prevent the Escape of Genes That Produce Specialty Chemicals. Plant Physiology, v. 132, p. 1770-1774. 2003.

FIORILLO, C. A. P. Biodiversidade e patrimônio genético no direito ambiental brasileiro. São Paulo: Max Limonad, 1999.

FOUREZ, G. A construção das ciências: introdução à filosofia e à ética das ciências. São Paulo: Editora da UNESP, 1995.

GARRAFA, V. Bioética e ciência: até onde avançar sem agredir. Revista CEJ, Brasília, 2010: Disponível em: <www2.cjf.jus.br/ojs2/index.php/cej/article/view/183/345.> Acesso em:10/07/2013.

GASKELL, G. Entrevistas Individuais e Grupais. In: Bauer, M.W.;Gaskell, G. (Eds.), Pesquisa qualitativa com texto, imagem e som: um manual prático. Petrópolis, RJ: Vozes, 2008. pp. 64-89.

GIL-PÉREZ, D. et al. Importância da educação científica na sociedade atual. In: Cachapuz, A., Gil-Pérez, D. Carvalho, A.M.P., Vilches, A. (Org.), A Necessária Renovaşão do Ensino de Ciências. São Paulo: Cortez, 2005. pp. 19-34.

GRIFFITHS, A. J. F. Introdução à Genética. Tradução de Paulo A. Mota. $9^{a}$ Edição. Rio de Janeiro: Guanabara Koogan, 2008. 740 p.

KOHLBERG, L. Psicologia del desarrollo moral. Bilbao (Espanha): Editorial Desclée de Brauwer S.A., 1992.

LACAZ-RUIZ, R.; CASTRO, F. C. P. A ciência e a bioética. Videtur, São Paulo, v. 6, n. 6, p. 15-20, 2004. Disponível em: <www.hottopos.com.br/videtur6/roger.htm> Acesso em: 10/07/2013.

LAPPÉ, M.; BAILEY, B. Against the grain: biotechnology and the corporate takeover of our food. Monroe, ME: Common Courage Press, 2000.

LA TAILLE, Y. Prefácio à edição brasileira. In: PUIG, J.M. A construção da personalidade moral. São Paulo: Ática, 1998.

LÜDKE, M. E ADRIANO, M.E.D.A. Pesquisa em educação: abordagens qualitativas. São Paulo: EPU, 2006.

MACHADO, P. A. L. Direito Ambiental Brasileiro. 11ªed. São Paulo: Malheiros, 2003.

MATTAR NETO, J. A. Filosofia e ética na administração. São Paulo: Saraiva, 2004. p. 1-34.

MORENO, C. Moral education in higher education and the transformation of a concern: a historical account. Paper apresentado na 31st Annual Meeting or the Association for Moral Education. Cambridge: Massachussets, 2008.

MOSCOVICI, S. A representação social da psicanálise. RJ: Zahar, 2004.

OLIVEIRA, A. L. de. Educação Ambiental: concepções e práticas de professores de Ciências do Ensino Fundamental. 2006. 139 f. Dissertação (Mestrado) - Universidade Estadual de Maringá, Maringá, PR, 2006. Disponível em <http://www.sfiec.org.br/iel/Teses/Tese4.pdf>. Acesso em: 10 de ago. de 2013.

PARTURY, F. e SCHELP, D. Transgênicos: os grãos que assustam. Revista Veja, São Paulo, 29.10.2003. PEDRANCINI, V. D. et al. Saber científico e conhecimento espontâneo: opiniões de alunos do ensino médio sobre transgênicos. Ciência \& Educação, Bauru, v. 14, n. 1, p. 135-146, 2008.

PIAGET, J. O juízo moral na criança. São Paulo: Summus, 1996. 
PIETROCOLA, M. Curiosidade e imaginação: os caminhos nas ciências, nas artes e no ensino. In: Ensino de Ciências: unindo a pesquisa e a prática. São Paulo: Thompson, 2004.

RAZERA, J.C.C.; NARDI, R. Ética no ensino de ciências: responsabilidades e compromissos com a evolução moral da criança nas discussões de assuntos controvertidos. Investigações no Ensino de Ciências, v.11, p. 53-66, 2006.

RAZERA, J.C.C. Ética em assuntos controvertidos no ensino de ciências: atitudes que configuram as controvérsias entre evolucionismo e criacionismo. 2000. 209f. Dissertação (Mestrado em Educação para a Ciência) - Faculdade de Ciências, Universidade Estadual Paulista, Bauru, 2000.

REST, J. et al. DIT Manual: manual for the defining issues test. Minneapolis: University of Minesota, 1999. RIECHMANN, J. Cultivos transgênicos e alimentos transgênicos. Petrópolis, RJ: Vozes, 2002.

SALVADOR, P. M. P. D. Avaliação do Impacto de Atividades Outdoor: Contributo dos Clubes de Ciência para a Alfabetização Científica. Dissertação (Mestrado em Geologia para o ensino) - Universidade do Porto, Porto, 2002.

SINGER, P. Ética prática. Trad. Jefferson Luiz Camargo. São Paulo: Martins Fontes, 2002. 399 p.

SIRVINSKAS, L. P. Manual de Direito Ambiental. $2^{a}$ ed. São Paulo: Saraiva, 2003.

SOLOMON, R. C. Ética e excelência: cooperação e integridade nos negócios. Trad. Maria Luiza X. de A. Borges. Rio de Janeiro: Civilização Brasileira, 2010. 460 p

TRASFERETTI, J. Ética e responsabilidade social. Campinas: Editora Alínea, 2006. 131 p.

VALE, J. M. F. Educação científica e sociedade. In: Nardi, R. (org). Questões atuais no ensino de Ciências. $2^{a}$ ed. São Paulo: Escrituras, 2009.

VALLS, A. L. M. O que é ética. $9^{a}$ ed. São Paulo: Brasiliense, 2000. 83 p

VÁZQUEZ, A. S. Ética. Trad. João Dell'Anna. 23a ed. Rio de Janeiro: Civilização Brasileira, 2002.

VASCONCELOS, C. S. Relação professor-aluno. In: Projeto de Educação Continuada: a escola pública e suas relações humano-sociais e educacionais. Bauru: SEE/UNESP/FUNDUNESP, 2008. p.53-58.

VERGARA, S.C. Métodos de Pesquisa em Administraşão. São Paulo: Atlas, 2008.

ZAJDSZNAJDER, L. Ética, estratégia e comunicaşão: na passagem da modernidade à pós-modernidade. Rio de Janeiro: FGV, 1999.

Data do Recebimento: 09/12/2013

Data de Aprovação: 06/02/2014

Data da Versão Final: 15/02/2014 